\title{
A Critical Role for Fibroblast Growth Factor-7 during Early Alveolar Formation in the Neonatal Rat
}

\author{
SANNA PADELA, MAN YI, JUDY CABACUNGAN, SAMUEL SHEK, ROSETTA BELCASTRO, AZHAR MASOOD, \\ ROBERT P. JANKOV, AND A. KEITH TANSWELL
}

\begin{abstract}
Canadian Institutes of Health Research Group in Lung Development [R.B., J.C., S.S., A.K.T.], Hospital for Sick Children Research Institute; Clinical Integrative Biology [R.P.J.], Sunnybrook Research Institute; Department of Paediatrics [R.P.J., A.K.T.], Department of Physiology [A.M., R.P.J., S.P., A.K.T., M.Y.], University of Toronto, Toronto, Ontario M5S 1A8, Canada
\end{abstract}

\begin{abstract}
Mesenchymal cell-derived FGF-7 (fibroblast growth factor-7) induces proliferation in both epithelial and endothelial cells. We found FGF-7 to be expressed in the lungs of neonatal rats from birth to d 14 of age. A role for FGF-7 in early postnatal lung growth and alveolar formation, by an action on type II pneumocytes, has been excluded by the work of others. However, a role through an action of FGF-7 on other cell types has not been excluded. We used intraperitoneal injections of neutralizing antibodies on $\mathrm{d} \mathrm{3,4}$, and 5 of life to inhibit binding of FGF-7 to its receptors, and assessed alveolar formation on d 6 of life. This intervention inhibited DNA synthesis in, and number of, alveoli-forming secondary crests, resulting in a significantly reduced alveolar number. This failure of alveolar formation was associated with a reduction in the number of small blood vessels in the lung periphery. We conclude that FGF-7, most likely through its effect on the vascular bed, is required for normal early postnatal alveolar formation from secondary crests. (Pediatr
\end{abstract} Res 63: 232-238, 2008)

A lveolar formation occurs largely (85\%) after birth in humans (1). In contrast to the regulators of early lung growth in utero, about which considerable information is available (2), relatively little is currently known about the factors that regulate postnatal lung growth and alveologenesis. Included in these regulators are likely to be numerous growth factors acting in concert. The roles of specific growth factors in the postnatal lung have only recently begun to be defined in detail. Animal studies have suggested roles for plateletderived growth factor (PDGF)-AA (3) and -BB (4), VEGF (5) and hepatocyte growth factor (HGF) (6).

In the neonatal rat, alveolar formation is a completely postnatal event (1). Alveolar number increases linearly over the first 3 wk of life in the rat (7). However, alveolar density

Received September 24, 2007; accepted October 3, 2007.

Correspondence: A. Keith Tanswell, Division of Neonatology, The Hospital for Sick Children, 555 University Avenue, Toronto, Ontario M5G 1X8, Canada; e-mail: keith.tanswell@sickkids.ca

This work was supported by group and operating (A.K.T., R.P.J) grants from the Canadian Institutes of Health Research (CIHR), and an infrastructure grant from the Canada Foundation for Innovation New Opportunities Fund (RPJ). RPJ is supported by a Career Development Award from the Canadian Child Health Clinician Scientist Program, a CIHR Strategic Training Program. AKT holds the Hospital for Sick Children Women's Auxiliary Chair in Neonatal Medicine. peaks on $\mathrm{d} 8$ of life, and does not increase thereafter (8). This is consistent with the two-phase model of lung growth. During the early phase of increasing alveolar density, alveolar formation is by a process of in-growth of secondary crests into prealveolar saccules (9). Subsequently, from d 8 onwards, alveolar formation is by acinar extension, with alveoli added distally, and does not require secondary crest formation (10). Our focus has been on defining those growth factors that regulate the initial phase of alveolar formation by the ingrowth of secondary crests.

Fibroblast growth factor-7 (FGF-7), also known as keratinocyte growth factor, stimulates DNA synthesis in alveolar epithelial cells (11) and endothelial cells (12) but not fibroblasts. FGF-7 is known to be involved in lung branching morphogenesis in utero (13). That FGF-7 can also influence alveolar formation is suggested by the observation that it can enhance compensatory lung growth (14). Any such effect in normal postnatal alveologenesis is unlikely to be due to an action of FGF-7 on epithelial cells, in that mice conditionally expressing a mutant epithelial cell membrane-bound FGF receptor-2 do not have impaired alveolar formation (15). However, this finding does not preclude an effect of FGF-7 on alveologenesis through an action on other cell types, such as the endothelial cell.

\section{MATERIALS AND METHODS}

Materials. Ethyl ether was from Caledon Laboratories (Georgetown, ON, Canada). Normal goat serum (NGS) was from Flow Laboratories (McLean, VA). Growth factor peptide and enzyme immunoassay kits for FGF-7 were from R \& D Systems (Minneapolis, MN). Paraformaldehyde and formaldehyde were from BDH Inc. (Toronto, ON, Canada). Acids, alcohols, chromatography-grade organic solvents, hydrogen peroxide, Permount, and Superfrost/Plus microscope slides were purchased from Fisher Scientific (Markham, ON, Canada). Donkey anti-goat and goat anti-rabbit secondary antibodies and recombinant FGFs were from Santa Cruz Biotechnology (Santa Cruz, CA). Avidin-biotin-peroxidase complex immunohistochemistry kits, and 3, 3'-diaminobenzidine were from Vector Laboratories (Burlingame, $\mathrm{CA})$. Bromodeoxyuridine (BrdU) and an in situ BrdU immunostaining kit were from BD Biosciences (Mississauga, ON, Canada).

Abbreviations: BrdU, bromodeoxyuridine; FGF, fibroblast growth factor; Flk-1, VEGF receptor-2; HGF, hepatocyte growth factor; vWF, von Willibrand factor 
Institutional review. Animal studies were conducted in accordance with criteria established by the Canadian Council on Animal Care. Approvals were obtained from the Animal Care Review Committees of the Sunnybrook and Women's, and Hospital for Sick Children, Research Institutes.

In vivo interventions. For neutralizing antibody interventions, pups received intraperitoneal injections of $100 \mu \mathrm{g}$ of either neutralizing mouse anti-human FGF-7 IgG (Clones \#29522.111 or, for confirmation studies, \#29568, R \& D Systems), or isotype-specific IgG (Santa Cruz Biotechnology), in $100 \mu \mathrm{L}$ PBS on d 3, 4, and 5 of life. To assess DNA synthesis, some pups received $20 \mu \mathrm{g} / \mathrm{g}$ i.p. BrdU (16) on d 6 of life. This was injected into the right iliac fossa through a 30-gauge needle $2 \mathrm{~h}$ before sacrifice by ether inhalation.

Immunohistochemistry. After flushing the pulmonary circulation with $1 \times$ PBS containing 1 unit $/ \mathrm{mL}$ heparin, to clear the lungs of blood, the lungs were perfusion-fixed under a constant airway pressure of $20 \mathrm{~cm}$ water, and sections were cut and mounted for immunostaining as previously described (6) Primary antibody dilutions used were as follows: anti-BrdU 1:10 (mouse monoclonal, Biosciences, BD PharMingen, San Diego, CA); anti-FGF-7 1:50 and anti-HGF 1:33 (goat polyclonal, Santa Cruz Biotechnology); anti-elastin 1:2,600 (goat polyclonal, Elastin Products, Owensville, MO); anti-vWF 1:200 (rabbit polyclonal, Thermo Scientific, Fremont, CA); anti-von Willibrand factor (VEGF) (A-20) 1:60 and anti-Flk-1 (C-20) 1:200 (goat anti-rabbit polyclonal, Santa Cruz Biotechnology). Species-specific secondary antibodies were diluted 1:200. A fluorescent secondary antibody was used for studies of vWF (Alexa Fluor 488, A11008, Invitrogen, Carlsbad, CA). Negative controls were generated either by omission of the primary antibody or, when available, by preincubation with the appropriate blocking peptide $(1: 100)$. For detection of BrdU, immunoperoxidase staining was performed using a biotinconjugated mouse MAb as part of a commercially available in situ detection kit, according to the manufacturer's instructions. All sections exposed to an individual antibody were stained in parallel. Images of stained sections were digitally captured using a Leica DC200 camera and Leica DC Viewer software (Leica Microsystems AG, Wetzlar, Germany). The total number of BrdU-positive cells within an image were expressed per unit area of the total image.

FGF-7 quantitation. The pulmonary circulation was flushed with PBS containing 1 unit $/ \mathrm{mL}$ heparin until the lungs became white, under a constant airway inflation pressure of $20 \mathrm{~cm}$ water. The lungs were then homogenized and sonicated (40 Watts for $30 \mathrm{~s}$ ) in cell lysis buffer $[10 \mathrm{mM}$ monosodium phosphate, $0.3 \mathrm{M}$ sodium chloride, $0.1 \%$ (wt/vol) SDS, $1 \%$ (vol/vol) Nonidet $\mathrm{P}-40,1 \%$ (vol/vol) sodium deoxycholate, $2 \mathrm{mM}$ disodium phosphate, $\mathrm{pH} 7.2]$ with the protease inhibitors leupeptin, aprotinin $(1 \mu \mathrm{g} / \mathrm{mL}$ each) and $1 \mathrm{mM}$ phenylmethanesulfonyl fluoride. The homogenate was left on ice for $10 \mathrm{~min}$ and then centrifuged at $7000 \times g$ for $10 \mathrm{~min}$. Supernatants were stored at $-80^{\circ} \mathrm{C}$ until analysis. FGF-7 content was measured using a commercially available ELISA kit (R \& D Systems) according to the manufacturer's instructions. Total protein contents of the supernatants were measured according to Bradford (17).

Morphometric analyses. Only lungs that were evenly inflated were used for morphometric analyses. Care was taken to ensure that all lungs were randomly oriented for embedding in paraffin. The blocks were cut into $5-\mu \mathrm{m}$ sections, then immunostained for elastin to enhance recognition of secondary crests. Images were then randomly taken from 10 nonoverlapping fields from each section, with four sections per animal and four animals per group. Mean linear intercepts were measured as described by Dunnill (18). Light microscopy, using a $\times 25$ objective and $\times 8$ ocular lens with a crossed hairline of known length, was used to determine intercept numbers (1 count for distal lung tissue intercept and 0.5 for airway or vessel wall intercept). Mean values from each animal were expressed in micrometers. Alveolar surface area per unit lung volume was calculated as described by Kawakami et al. (19). Pixel Parser Plugins (available from Daryl Humes: dghumes@student.math.uwaterloo.ca) and Image $\mathbf{J}$ software (National Institutes of Health, Bethesda, MD) were used to calculate tissue fractions/image from pixel counts of black-and-white images that had been derived from grayscale images. Secondary crests per unit area, and the ratio of BrdU-positive to total secondary crests, were derived from the total number of attached secondary crests in an image of known area, irrespective of their length. Ratios of secondary crests to tissue were derived using a superimposed grid, and counting the number of points overlying secondary crests or other tissue. Total alveolar numbers were calculated as described by Weibel and Gomez (20). Water displacement was used to measure postfixation lung volumes.

Counting small vessels in the lung periphery. For detection of perivascular elastin rings, sections were stained with a Hart's resorcin-fuchsin solution (Elastin Products, Owensville, MO). After deparaffinization and hydration, sections were submerged in a working solution of resorcin-fuchsin overnight. After washing, the sections were counterstained with tartrazine, rinsed, dehydrated, cleared in xylene, and mounted using Permount. Concen-

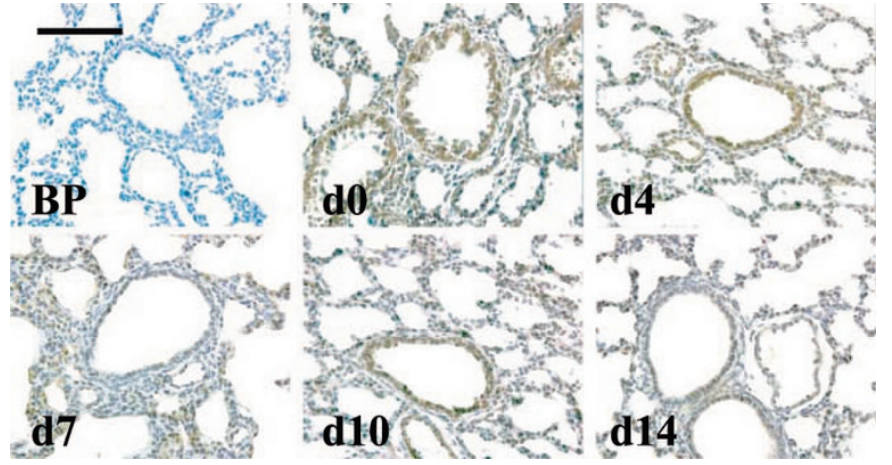

Figure 1. Immunohistochemistry for FGF-7 in lung sections from pups at the day of birth (d 0 ), or after $4,7,10$, or $14 \mathrm{~d}$ (d 4-14). As a negative control, sections were immunostained after immunoadsorption of the primary antibody with the blocking peptide $(B P)$ against which the antibody had been raised. $\mathrm{Bar}=100 \mu \mathrm{m}$.

tric rings of 20 and $65 \mu \mathrm{m}$ diameters were superimposed on images, and only those vessels with outer elastin band diameters within this range were counted. The number of peripheral vessels of $20-65 \mu \mathrm{m}$ in diameter was counted in 10 random nonoverlapping fields/lung, with all fields being within $435 \mu \mathrm{m}$ of the edge of the lung on tissue cross-section. Fields with no identified vessels within the selected range were not excluded from the analysis.

Western analyses. Western analysis was conducted as previously described (6). Each lane was loaded with $10 \mu \mathrm{g}$ of recombinant human FGF-1, -2, -3, -4, -7, -10, or -12. Primary (clone \# 29522) and secondary anti-isotype IgG antibody concentrations were 1:1,000 and 1:10,000, respectively.

Data presentation. All values are for mean \pm SEM. Values for protein quantitation were derived from four separate litters, within each of which lungs from four average-sized pups had been pooled. All other values are from four or more average-sized pups obtained from different litters. When comparisons involved only two groups, two-tailed $t$ test was used, whereas for all other comparisons of multiple groups, one-way ANOVA was used to determine statistical significance $(p<0.05)$. ANOVA was followed by a post hoc analysis using Duncan's multiple range test when significant differences were found between groups (21)

\section{RESULTS}

Expression of FGF-7. We had anticipated that if FGF-7 was involved in early alveologenesis from secondary crest formation, it would have an expression profile in the early

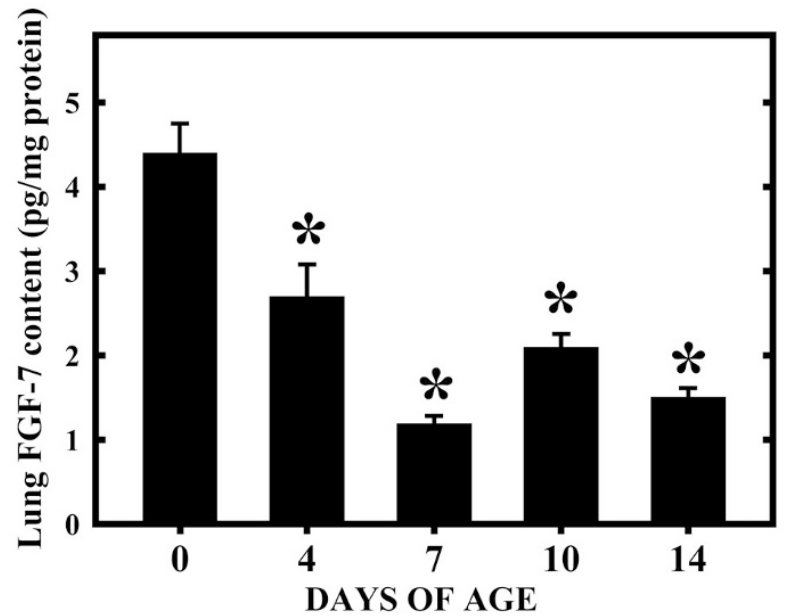

Figure 2. Lung content of FGF-7 was quantified by ELISA. $* p<0.05$ by one-way ANOVA compared with lung FGF-7 content of pups at d 0. Lungs from four average-sized pups in each litter of 10-12 pups were pooled. Values are means \pm SEM for four litters in each group. 
postnatal rat lung similar to that previously observed for PDGF-AA, PDGF-BB, and HGF $(4,6)$. The expression of these growth factors, known to regulate early alveolar formation, increased on $\mathrm{d} 4-7$ of life, during the period of secondary crest formations, and declined thereafter. This was not the case for FGF-7. As assessed by immunohistochemistry, lung FGF-7 content declined after birth but remained easily detectable with distribution being similar on $\mathrm{d} 4,7,10$, and 14 of life (Fig. 1). Consistent with the qualitative assessment by immunohistochemistry, quantitation by ELISA confirmed a significant initial decline in lung FGF-7 content after birth, with similar contents in the lungs on d 4, 7, 10, and 14 (Fig. 2). Apart from FGF-7 being immunolocalized to airway and distal air sac epithelium, it was also readily detectible around small peripheral vessels (Fig. 3).

Effect of anti-FGF-7 IgG on early postnatal alveolar formation. Although the expression profile for FGF-7 differed from other growth factors regulating secondary crest formation, we could not exclude it having a role without a targeted intervention study. For this purpose, we injected rat pups intraperitoneally with anti-FGF-7 IgG to bind circulating FGF-7 and prevent its binding to its natural receptors. As assessed by Western blot, the antibody selected for interventional use did not cross-react with FGF-1, $-2,-3,-4,-10$, or -12 (Fig. 4), supporting its specificity. Pups that had received intraperitoneal neutralizing antibodies to FGF-7 on d 3, 4, and 5 of life had normal total body weights, but reduced lung weights and lung/body weight ratios on d 6 of life, when compared with values for uninjected control animals, or animals that had received an isotype antibody (Table 1). There were no differences found for postfixation lung volumes between the three groups, but the fraction of lung occupied by tissue was significantly reduced in those pups that had received anti-FGF-7 IgG (Table 1). Consistent with the observed reductions in lung weight, lung/body weight ratio and tissue fraction was the finding that treatment with the antiFGF-7 IgG also affected total lung cell DNA synthesis, as assessed by the number of cells that had taken up BrdU (Table 1). Upon histologic examination of d-6 lung sections, pups that had received the intraperitoneal anti-FGF-7 IgG had an apparent gross simplification of lung morphology, relative to that of isotype $\mathrm{IgG}$-injected control pups or uninjected pups. The lung structure of the pups that had received the intraperitoneal anti-FGF-7 IgG resembled the structure normally present at d 3 of life, the day on which injections were commenced (Fig. 5).

This apparent simplification of lung structure, following treatment with intraperitoneal anti-FGF-7 IgG, was con-
FGF-7 Antibody

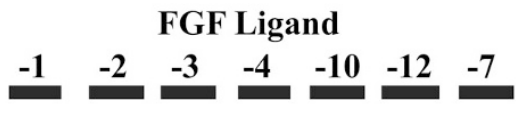

\# 29522

$\begin{aligned} \text { kDa } & = \\ 98 & = \\ 38 & = \\ 28 & = \\ 17 & =\end{aligned}$

Figure 4. Western analysis of the specificity of the initial anti-FGF-7 antibody used for intervention (clone \#29522). Members of the FGF family, FGF-1, $-2,-3,-4,-10,-12$, and -7 , were loaded at $10 \mu \mathrm{g} / \mathrm{lane}$ and probed with the antibody. Clone \#29522 recognized only FGF-7.

firmed by morphometry. In the group of pups that had received the intraperitoneal anti-FGF-7 $\mathrm{IgG}$, there was a significant decrease in the number of secondary crests per unit area (Fig. 6 A). Fixation artifact could be excluded as a cause for this decrease because a significant decrease was also evident in the ratio of secondary crests to tissue in the pups treated with anti-FGF-7 IgG (Fig. 6 B). A decrease in the ratio of secondary crests to tissue, as assessed by point counting, may reflect not just a reduction in the number of crests but also a reduction in their length or surface area. The reduction in the number of secondary crests was associated with an apparent reduction in the number of secondary crests containing cells undergoing active DNA synthesis, as assessed by BrdU immunoreactivity (Fig. 7). This apparent decrease was confirmed by expressing the number of crests containing immunoreactive cells either as a ratio to tissue (Fig. $6 \mathrm{C}$ ), or as a proportion of the total number of secondary crests (Fig. $6 \mathrm{D}$ ).

To determine whether the above effects of treatment with intraperitoneal anti-FGF-7 IgG on secondary crests translated into an inhibition of alveolar formation, we measured its effects on mean linear intercepts, which were significantly increased (Fig. $8 \mathrm{~A}$ ), and alveolar surface area (Fig. $8 \mathrm{~B}$ ), alveolar density (Fig. $8 \mathrm{C}$ ), and total alveolar number (Fig. 8 $D$ ), which were all significantly decreased. We then tested our impression that the lung on d 6 of life, after treatment with intraperitoneal anti-FGF-7 IgG, resembled the lung from untreated pups on d 3 of life. No significant differences were found in the values for mean linear intercept, alveolar surface area, alveolar density, secondary crests per unit area or the secondary crest/tissue ratio, on d 6 of life after treatment with the anti-FGF-7 IgG, when compared with values for untreated pups on d 3 of life (Table 2).
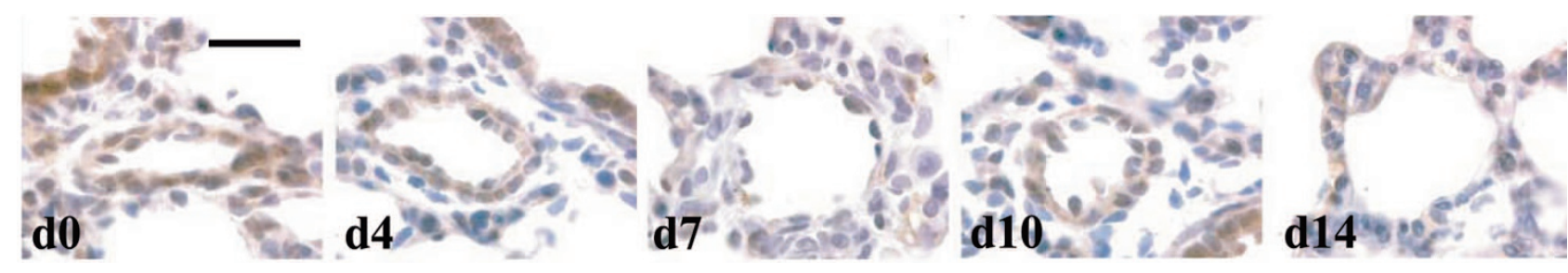

Figure 3. Immunohistochemistry for FGF-7, when viewed at high power, localized FGF-7 around small pulmonary vessels on the day of birth (d 0), or after $4,7,10$, or $14 \mathrm{~d}(\mathrm{~d} 4-14)$. Bar $=25 \mu \mathrm{m}$. 
Table 1. Indices of lung and body growth from 6-d-old rat pups that were either untreated or had been injected with isotype IgG or anti-FGF-7 neutralizing antibody

\begin{tabular}{lccc}
\hline \multicolumn{1}{c}{ Analysis } & Untreated $($ mean \pm SEM) & Isotype IgG (mean \pm SEM) & Anti-FGF-7 IgG (mean \pm SEM) \\
\hline Lung weight $(\mathrm{mg})$ & $234 \pm 17(9)$ & $226 \pm 9(5)$ & $206 \pm 9 *(5)$ \\
Body weight $(\mathrm{g})$ & $13.6 \pm 0.3(9)$ & $13.9 \pm 0.4(5)$ & $13.4 \pm 0.3(5)$ \\
Lung/body weight ratio $\times 10^{2}$ & $1.73 \pm 0.17(9)$ & $1.63 \pm 0.10(5)$ & $1.54 \pm 0.52^{*}(5)$ \\
Lung volume $(\mu \mathrm{L})$ & $612 \pm 20(4)$ & $568 \pm 28(4)$ & $635 \pm 19(4)$ \\
Tissue fraction & $0.32 \pm 0.03(4)$ & $0.27 \pm 0.01(4)$ & $0.22 \pm 0.01^{*}(4)$ \\
BrdU-positive cells $/ \mathrm{mm}^{2}$ & $377 \pm 29(4)$ & $390 \pm 16(4)$ & $227 \pm 26^{*}(4)$ \\
\hline
\end{tabular}

$n$ Values are shown in parentheses.

$* p<0.05$ by one-way ANOVA compared with values for animals that had received vehicle alone.

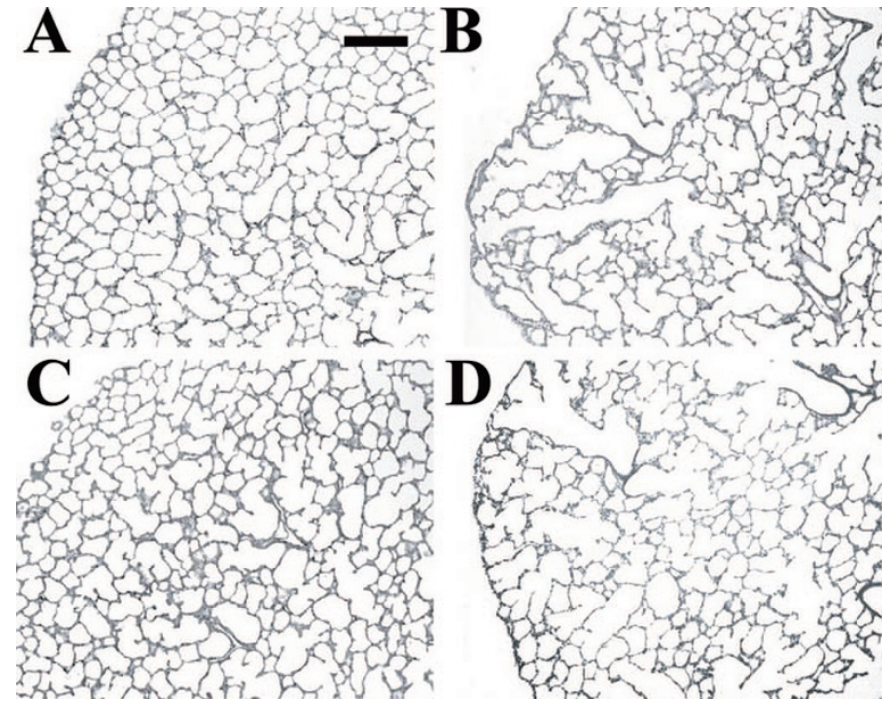

Figure 5. Lung sections from pups at $6 \mathrm{~d}$ of age that had been injected with anti-FGF-7 IgG $(B)$ revealed a simplified lung structure, when compared with those of uninjected control pups $(C)$ or pups injected with isotype $\operatorname{IgG}(A)$. The lung sections from pups at $6 \mathrm{~d}$ of age that had been injected with anti-FGF-7 IgG had an appearance similar to that seen on d 3 of life $(D)$, consistent with an inhibition of alveolar formation. Bar $=200 \mu \mathrm{m}$.

Treatment with intraperitoneal anti-FGF-7 IgG, as would be predicted from its associated reduction in alveolar number and tissue fraction, appeared to reduce vessel density in the peripheral lung, as illustrated by immunostaining for vWF (Fig. 9) to identify endothelial cells (22). The reduction in peripheral vessel density did not appear to be limited to just the smallest vessels, capillaries. It also included vessels with an outer elastin ring of 20-65 $\mu \mathrm{m}$ diameter, likely arterioles, as assessed by direct counts (Fig. 10).

HGF as an up- or down-stream regulator of FGF-7 expression. As assessed by immunohistochemistry, treatment with anti-FGF-7 IgG had no obvious gross effect on the expression of immunoreactive $\mathrm{HGF}$, nor did injection of anti-HGF IgG, as previously described (6), have any apparent gross effect on FGF-7 expression (data not shown).

HGF as an up-stream regulator of VEGF or VEGF receptor-2 (Flk) expression. As assessed by immunohistochemistry, treatment with anti-FGF-7 IgG had no obvious gross effect on the expressions of either immunoreactive VEGF or Flk-1 (data not shown).

Antibody specificity. As a further confirmation of the specificity of our findings with the antibody used for the above studies, we repeated selected measurements after identical
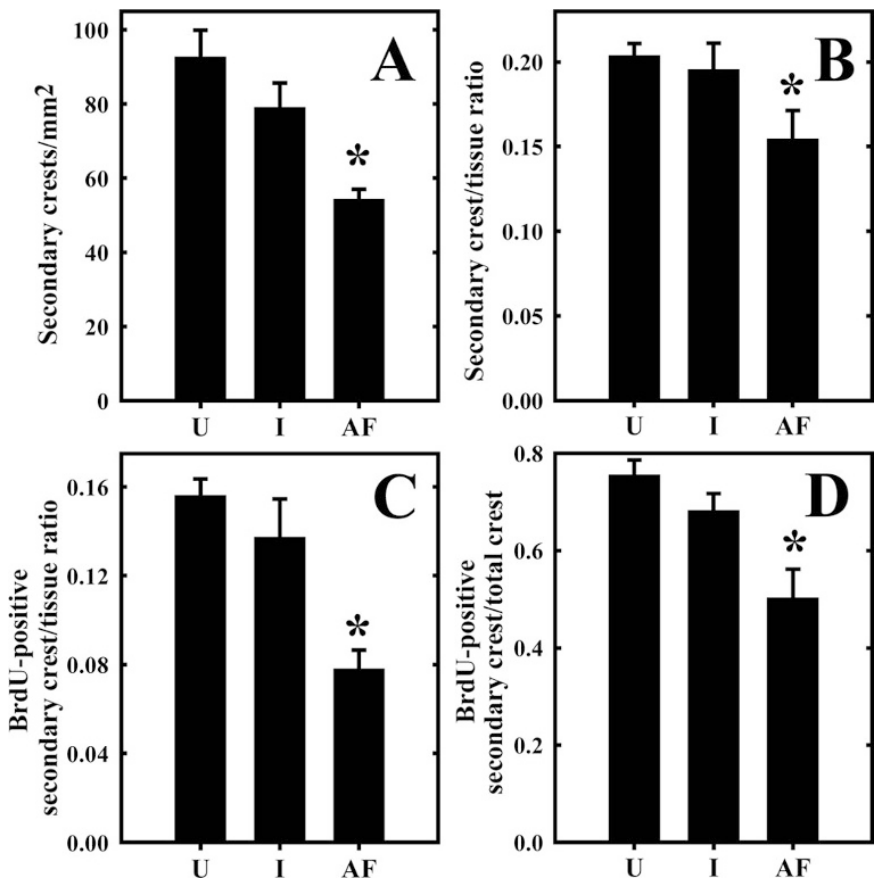

Figure 6. Treatment of rat pups with anti-FGF-7 $\operatorname{IgG}(A F)$ significantly reduced the number of secondary crests/unit area $(A)$, the secondary crest/ tissue ratio $(B)$, the BrdU-immunoreactive (BrdU-positive) secondary crest/ tissue ratio $(C)$, and the proportion of secondary crests that were BrdUpositive $(D)$ on d 6 of life, relative to pups that were either uninjected $(U)$ or had received a control isotype $\operatorname{IgG}(I) .{ }^{*} p<0.05$ by one-way ANOVA, compared with values for uninjected animals or animals that had received a control isotype IgG. For each treatment group, values are means \pm SEM for four average-sized pups from different litters.

treatments using intraperitoneal injections of a different neutralizing antibody to FGF-7. We reasoned that two antibodies raised against different peptide sequences in the growth factor would be unlikely to cross-react, if at all, with the same ligand. The second anti-FGF-7 IgG also resulted in a decrease in secondary crest density, a decrease in the ratio of both BrdUlabeled and unlabeled secondary crests to tissue, and a decrease in the proportion of secondary crests labeled by BrdU (Table 3).

\section{DISCUSSION}

Endogenous FGF-7 production has been shown by others to regulate diverse aspects of lung development and function (23). However, a role in normal postnatal alveolar formation has not, to our knowledge, been previously described.

Because the rapid increase in alveolar density, secondary to the process of secondary septation, occurs in neonatal rat 


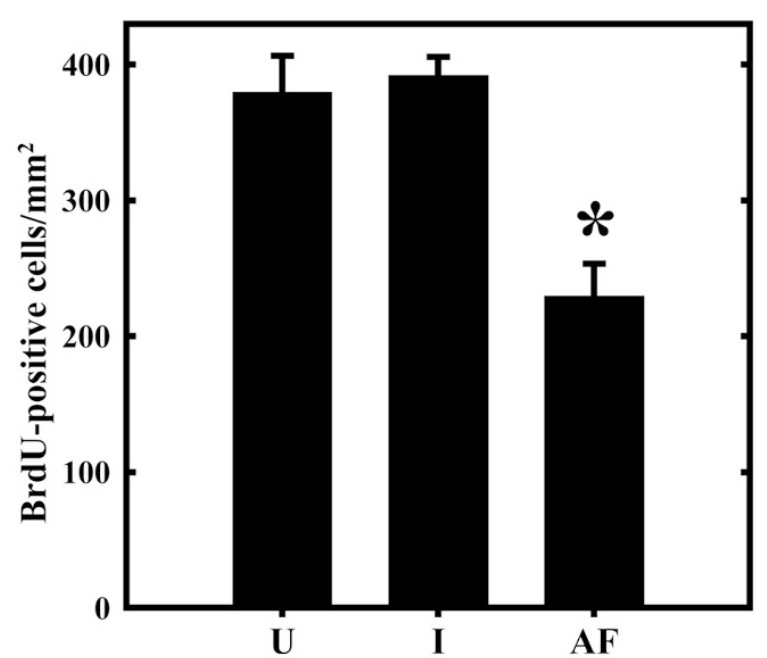

Figure 7. Rat pups that had received anti-FGF-7 $\operatorname{IgG}(A F)$ had a significantly reduced number of BrdU-immunoreactive (BrdU-positive) lung cells/unit area on $\mathrm{d} 6$ of life, when compared with pups that were either uninjected $(U)$ or had received a control isotype $\operatorname{IgG}(I) * p<0.05$ by one-way ANOVA, compared with values for uninjected animals or animals that had received a control isotype IgG. For each treatment group, values are means \pm SEM for four average-sized pups from different litters.
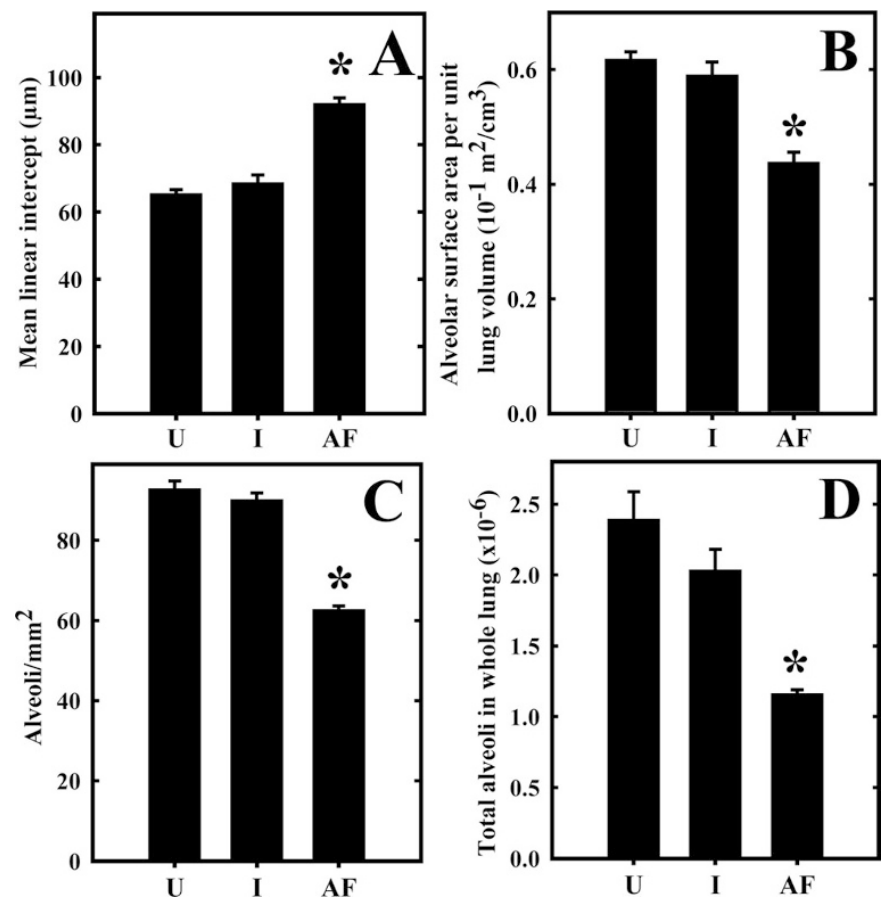

Figure 8. Treatment of rat pups with anti-FGF-7 $\operatorname{IgG}(A F)$ significantly increased the mean linear intercept $(A)$, and significantly decreased the alveolar surface area $(B)$, the number of alveoli/unit area $(C)$, and the total lung alveolar count $(D)$ on d 6 of life, relative to pups that were either uninjected $(U)$ or had received a control isotype $\operatorname{IgG}(I)$. ${ }^{*} p<0.05$ by one-way ANOVA compared with values for uninjected animals or animals that had received a control isotype $\mathrm{IgG}$. For each treatment group, values are means \pm SEM for four average-sized pups from different litters.

lung between d 3 and 8 of life (8), we timed our intervention studies to fall within this window. Specifically, pups received intraperitoneal injections of anti-FGF-7 antibodies on $\mathrm{d} 3,4$, and 5 and were subsequently killed on $\mathrm{d} 6$. When taken together, our results suggest that anti-FGF-7 antibod-
Table 2. Comparison of morphometric data from the lungs of 3-d-old untreated rat pups, or 6-d-old rat pups that had been injected with anti-FGF-7 neutralizing antibody

\begin{tabular}{lcc}
\hline \multicolumn{1}{c}{ Analysis } & $\begin{array}{c}\text { Day } 3 \text { untreated } \\
(\text { mean } \pm \text { SEM) }\end{array}$ & $\begin{array}{c}\text { Day 6 } \\
\text { anti-FGF-7 IgG } \\
(\text { mean } \pm \text { SEM })\end{array}$ \\
\hline Mean linear intercept $(\mu \mathrm{m})$ & $83.8 \pm 5.3$ & $91.9 \pm 2.1$ \\
Alveolar surface area per unit & $0.465 \pm 0.010$ & $0.436 \pm 0.010$ \\
$\quad$ lung volume $\left(10^{-1} \mathrm{~m}^{2} / \mathrm{cm}^{3}\right)$ & & \\
Alveoli/ $/ \mathrm{mm}^{2}$ & $66.8 \pm 1.3$ & $62.4 \pm 1.2$ \\
Secondary crests $/ \mathrm{mm}^{2}$ & $50.3 \pm 0.8$ & $53.8 \pm 3.1$ \\
Secondary crest/tissue ratio & $0.096 \pm 0.009$ & $0.154 \pm 0.018$ \\
\hline
\end{tabular}

$n=4-6$ average-sized pups in each group.
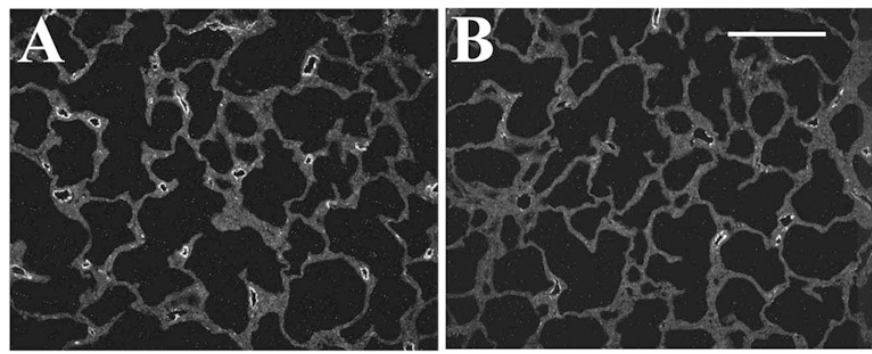

Figure 9. Fluorescent immunohistochemistry for vWF, to label endothelial cells. When compared with animals that had received a control isotype $\operatorname{IgG}$ $(A)$, treatment of rat pups with anti-FGF-7 $\operatorname{IgG}(B)$ reduced vessel density in the peripheral lung. Bar $=200 \mu \mathrm{m}$.

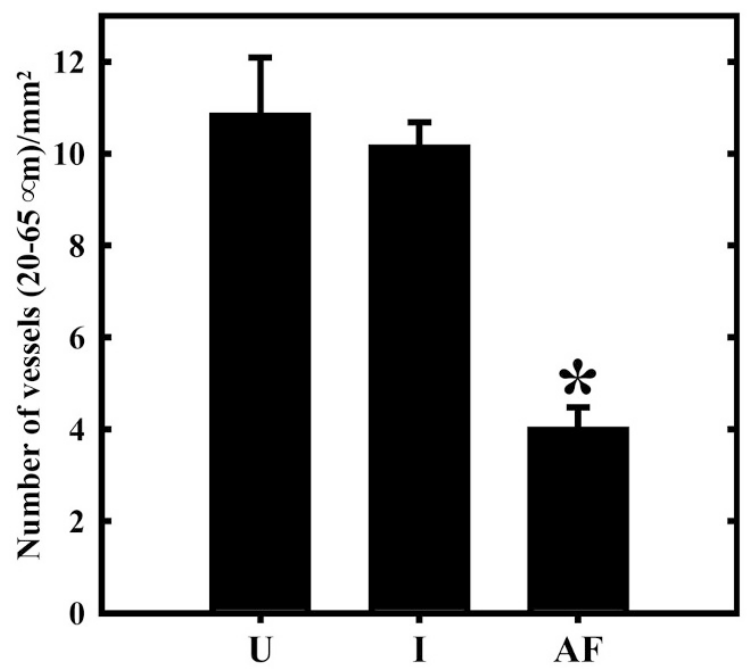

Figure 10. Small vessels in the lung periphery with outer elastin rings, identified using Hart's stain, of 20-65 $\mu \mathrm{m}$ diameter were counted. Treatment of rat pups with anti-FGF-7 IgG $(A F)$ significantly reduced vessel number when compared with values for uninjected animals $(U)$ or animals that had received a control isotype $\operatorname{IgG}(I)$. ${ }^{*} p<0.05$ by one-way ANOVA. Values are means \pm SEM for four average-sized pups from different litters.

ies caused an inhibition of DNA synthesis in secondary crests, with a resultant inhibition of secondary crest ingrowth from the walls of precursor saccules and a consequent inhibition of alveolar formation. Pups treated with the anti-FGF-7 antibody had an obvious gross simplification of their lung structure. Morphometric analysis suggested that there had been little progress in alveolar formation following initiation of treatment with anti-FGF-7 antibody on d 3 of life. It will be of interest to determine in 
Table 3. Selected morphometric parameters were measured in 6-d-old rat pups that were either untreated or had been injected with isotype IgG or a second anti-FGF-7 neutralizing antibody, to confirm the specificity of the first antibody used for all the other studies

\begin{tabular}{lccc}
\hline \multicolumn{1}{c}{ Analysis } & $\begin{array}{c}\text { Untreated } \\
(\text { mean } \pm \text { SEM) }\end{array}$ & $\begin{array}{c}\text { Isotype IgG } \\
(\text { mean } \pm \text { SEM) }\end{array}$ & $\begin{array}{c}\text { Anti-FGF-7 IgG } \\
(\text { mean } \pm \text { SEM) }\end{array}$ \\
\hline Secondary crests $/ \mathrm{mm}^{2}$ & $85.9 \pm 4.4$ & $82.3 \pm 4.8$ & $49.0 \pm 4.0^{*}$ \\
Secondary crest/tissue ratio & $0.182 \pm 0.004$ & $0.198 \pm 0.014$ & $0.134 \pm 0.016^{*}$ \\
BrdU-positive secondary crest/tissue ratio & $0.133 \pm 0.003$ & $0.126 \pm 0.006$ & $0.064 \pm 0.013^{*}$ \\
BrdU-positive secondary crest/total crest ratio & $0.729 \pm 0.024$ & $0.622 \pm 0.030$ & $0.415 \pm 0.055^{*}$ \\
\hline
\end{tabular}

$n=4$ average-sized pups in each group.

$* p<0.05$ by one-way ANOVA compared with values for animals that had received vehicle alone.

a future study if pups can recover from their arrested secondary septation during the subsequent phase of alveologenesis by peripheral extension.

In a previous study, in which we examined the role of HGF in alveologenesis, we were able to replicate the effects of an antibody to HGF using a decoy truncated soluble HGF receptor intervention (6). This finding confirmed the specificity of the antibody used, because HGF binds to a single receptor, c-Met, which does not bind other growth factors. We were unable to take a similar approach for studies of FGF-7. FGF-7 does bind to a specific FGF receptor on epithelial cells, the FGFR2-IIIb splice variant isoform. Unfortunately, the FGFR2-IIIb is not specific for a single ligand and binds a subset of the FGF family, including FGF-1, -3, -7, and -10 (24-26), preventing the use of a truncated soluble FGFR2-IIIb to confirm the specificity of the antibody for FGF-7. The antibody used in the initial intervention study did not cross-react with other members of the FGF family. To further compensate for this lack of a suitable soluble receptor, we used a second neutralizing antibody to FGF-7, raised against a different peptide sequence of FGF-7, to replicate key findings generated with the original neutralizing antibody, thus confirming its specificity. A similar gross simplification of lung structure was observed with injection of the second anti-FGF-7 antibody.

FGF-7 and HGF are both critical factors for normal postnatal alveologenesis, yet do not share a common receptor. Interventions that target FGF-7 appear to arrest secondary crest development at the stage present at the onset of the intervention. This was also true for previous interventions that had targeted HGF (6). At first glance, this suggests that they are both critical, but independent, components of the events which lead to alveolar formation from secondary crests. However, there is evidence in other organs that FGF-7 and HGF may be interdependent, with FGF-7 stimulating HGF mRNA and protein expression (27). When screened by immunohistochemistry we saw no evidence that anti-FGF-7 antibody injection had had any major effect on HGF expression. Nor did we find any major effect of anti-HGF antibody injection on FGF-7 expression.

Hokuto et al. (15) have previously demonstrated, using conditional expression of a transgene for a mutant membrane-associated soluble FGF receptor, that postnatal inhibition of the FGFR2-IIIb pathway on lung epithelial cells did not affect alveologenesis. This finding suggests that our observed inhibition of alveologenesis with an anti-FGF-7 IgG may be mediated by inhibition of its binding to recep- tors on endothelial cells, some of which are distinct from FGFR2-IIIb but as yet uncharacterized (12). Exposure to FGF-7 can induce angiogenesis (12) and inhibition of angiogenesis is sufficient to arrest alveolar formation (5). Our finding that the injection of anti-FGF-7 IgG resulted in a significant reduction in the number of small vessels in the lung periphery, in addition to inhibiting alveologenesis, is consistent with these observations. It did not exclude the possibility that FGF-7 acts up-stream of another growth factor known to influence angiogenesis and alveologenesis, such as VEGF (5), though we saw no gross change in immunoreactive VEGF or Flk-1.

We conclude that FGF-7 does play a critical role in early alveologenesis mediated by secondary crest formation, and that this effect is most likely mediated through its actions on endothelial cells.

\section{REFERENCES}

1. Burri PH 1997 Structural aspects of prenatal and postnatal development and growth of the lung. In: McDonald JA (ed) Lung Growth and Development. Marcel Dekker, New York, pp 1-35

2. Post M, Tanswell K 2002 Embryonic lung development. In: Wardlaw AJ, Hamid $\mathrm{Q}$ (eds) Textbook of Respiratory Cell and Molecular Biology. Dunitz, London, pp 3-14

3. Lindahl P, Karlsson L, Hellstrom M, Gebre-Medhin S, Willetts K, Heath JK, Betsholtz C 1997 Alveogenesis failure in PDGF-A-deficient mice is coupled to lack of distal spreading of alveolar smooth muscle cell progenitors during lung development. Development 124:3943-3953

4. Buch S, Han RN, Cabacungan J, Wang JX, Yuan SZ, Belcastro R, Deimling J, Jankov R, Luo XP, Lye SJ, Post M, Tanswell AK 2000 Changes in expression of platelet-derived growth factor and its receptors in the lungs of newborn rats exposed to air or $60 \%$ O2. Pediatr Res 48:423-433

5. Jakkula M, Le Cras TD, Gebb S, Hirth KP, Tuder RM, Voelkel NF, Abman SH 2000 Inhibition of angiogenesis decreases alveolarization in the developing rat lung. Am J Physiol Lung Cell Mol Physiol 279:L600-L607

6. Padela S, Cabacungan J, Shek S, Belcastro R, Yi M, Jankov RP, Tanswell AK 2005 Hepatocyte growth factor is required for alveologenesis in the neonatal rat. Am J Respir Crit Care Med 172:907-914

7. Randell SH, Mercer RR, Young SL 1989 Postnatal growth of pulmonary acini and alveoli in normal and oxygen-exposed rats studied by serial section reconstructions. Am J Anat 186:55-68

8. Meyrick B, Reid L 1982 Pulmonary arterial and alveolar development in normal postnatal rat lung. Am Rev Respir Dis 125:468-473

9. Burri PH 1984 Fetal and postnatal development of the lung. Annu Rev Physiol 46:617-628

10. Massaro D, Teich N, Maxwell S, Massaro GD, Whitney P 1985 Postnatal development of alveoli: regulation and evidence for a critical period in rats. J Clin Invest 76:1297-1305

11. Ulich TR, Yi ES, Longmuir K, Yin S, Biltz R, Morris CF, Housley RM, Pierce GF 1994 Keratinocyte growth factor is a growth factor for type II pneumocytes in vivo. J Clin Invest 93:1298-1306

12. Gillis P, Savla U, Volpert OV, Jimenez B, Waters CM, Panos RJ, Bouck NP 1999 Keratinocyte growth factor induces angiogenesis and protects endothelial barrier function. J Cell Sci 112:2049-2057

13. Post M, Souza P, Liu J, Tseu I, Wang J, Kuliszewski M, Tanswell AK 1996 Keratinocyte growth factor and its receptor are involved in regulating early lung branching. Development 122:3107-3115

14. Kaza AK, Kron IL, Leuwerke SM, Tribble CG, Laubach VE 2002 Keratinocyte growth factor enhances post-pneumonectomy lung growth by alveolar proliferation. Circulation 106:I120-I124 
15. Hokuto I, Perl A-K, Whitsett JA 2003 Prenatal, but not postnatal, inhibition of fibroblast growth factor receptor signaling causes emphysema. J Biol Chem 278:415-421

16. Gardner SY, Brody AR 1995 Incorporation of bromodeoxyuridine as a method to quantify cell proliferation in bronchiolar-alveolar duct regions of asbestos-exposed mice. Inhal Toxicol 7:215-224

17. Bradford MM 1976 A rapid and sensitive method for the quantitation of microgram quantities of protein utilizing the principle of protein-dye binding. Anal Biochem 72:248-254

18. Dunnill M 1962 Quantitative methods in the study of pulmonary pathology. Thorax $17: 320-328$

19. Kawakami M, Paul JL, Thurlbeck WM 1984 The effect of age on lung structure in male BALB/cNNia inbred mice. Am J Anat 170:1-21

20. Weibel ER, Gomez DM 1962 A principle for counting tissue structures on random sections. J Appl Physiol 17:343-348

21. Snedecor G, Cochran WG 1980 Statistical Methods. Iowa State University Press, Ames, IA, pp 215-237

22. McComb RD, Jones TR, Pizzo SV, Bigner DD 1982 Specificity and sensitivity of immunohistochemical detection of factor VIII/von Willebrand factor antigen in formalin-fixed paraffin-embedded tissue. J Histochem Cytochem 30: 371-377

23. Ware LB, Matthay MA 2002 Keratinocyte and hepatocyte growth factors in the lung: roles in lung development, inflammation, and repair. Am J Physiol Lung Cell Mol Physiol 282:L924-L940

24. Igarashi M, Finch PW, Aaronson SA 1998 Characterization of recombinant human fibroblast growth factor (FGF)-10 reveals functional similarities with keratinocyte growth factor (FGF-7). J Biol Chem 273:13230-13235

25. Ornitz DM, Xu J, Colvin JS, McEwen DG, MacArthur CA, Coulier F, Gao G, Goldfarb M 1996 Receptor specificity of the fibroblast growth factor family. J Biol Chem 271:15292-15297

26. Steiling H, Wustefeld T, Bugnon P, Brauchle M, Fassler R, Teupser D, Thiery J, Gordon JI, Trautwein C, Werner S 2003 Fibroblast growth factor receptor signalling is crucial for liver homeostasis and regeneration. Oncogene 22:4380 4388

27. Parrott JA, Mosher R, Kim G, Skinner MK 2000 Autocrine interactions of keratinocyte growth factor, hepatocyte growth factor, and kit-ligand in the regulation of normal ovarian surface epithelial cells. Endocrinology 141:2532-2539 